\title{
APPLICATION OF LINEAR PROGRAMMING IN SUPPLY CHAIN MANAGEMENT IN THE FOUNDRY
}

\author{
${ }^{1}$ Marek KRYNKE \\ ${ }^{1}$ Czestochowa University of Technology, Czestochowa, Poland, EU, marek.krynke@wz.pcz.pl
}

https://doi.org/10.37904/metal.2020.3648

\begin{abstract}
This article addresses the problem of supply chain management in the foundry industry. In the case of manufacturing companies assisting in the production process by external entities, it is important to consider cooperation starting from the settlement of raw materials or semi-finished products to the acceptance of production from a subcontractor along with the registration of the costs of service, transport and storage. Subcontractor's production plans should be included in the operational production schedule. The article solves a specific problem regarding cooperation with suppliers of alloying elements for the production of cast iron. A cast production, transport and storage plan has been developed so that the total costs of production, transport and storage are as low as possible. A mathematical model was formulated for this problem. An algorithm is presented to solve the problem of supplier selection. The proposed analysis is the starting point for an efficient business planning process, where it is required to transform information from various areas (sales, marketing and business partners) into a common set of planning data and indicators.
\end{abstract}

Keywords: Metallurgy, supply chain management, linear programing, optimization, octave

\section{INTRODUCTION}

Supply chain management (SCM) is the art of improving ways of obtaining raw materials and products needed by a company to manufacture products or provide services, improve production itself and methods of delivering them to clients [1-3]. In the case of manufacturing companies assisting in the production process by external entities, it is important to consider cooperation starting from the settlement of raw materials or semi-finished products to the acceptance of production from a subcontractor along with the registration of the costs of service, transport and storage. Subcontractor's production plans should be included in the operational production schedule [4]. Cooperation in supply networks is perceived by many distribution enterprises as an opportunity for more efficient adaptation to changes of the environment. Its role in product distribution increases especially on very dynamic markets, with variable demand and a short product life cycle. It is so because for such markets it is adequate is to use the postponed production strategy and the shift of the last stage of production from industrial companies to distribution enterprises [5,6].

In supply chain management, a large part of the planning process concerns the development of a set of measures to monitor the supply chain in terms of its efficiency and low costs, as well as high quality and value provided to clients [7]. A set of processes should be developed here for pricing, supplier selection and payment, and measures to monitor and improve supplier relationships. One should not forget about the processes of managing the inventory of goods and services received from suppliers, including processes related to the receipt and checking of deliveries, the transfer of deliveries to production departments, as well as the approval of payments to suppliers $[8,9]$.

This article discusses modelling of cooperation from the perspective of groups of production and distribution enterprise for the needs of complex fulfilment of orders in the foundry industry. The study took into account the problem of selecting alloy suppliers for cast iron production in the production and logistics network [10]. The 
research used the methodology used to solve the transport and production problem. The production transportation problem (PTP) is one of the very important problems in the continuous production industries such as petroleum industry. It deals with the problem of how to plan production and transportation in such an industry given several plants at different locations and large number of customers of their products. This problem has been addressed previously in the literature $[11,12]$ and can be formulated as a linear programming problem.

The model developed focuses on planning the production process in the event that the goods have not yet been produced and it is necessary to decide where to produce them and how to send them to recipients so that the total costs of production and transport (and possibly storage of surplus) are as low as possible.

\section{PRODUCTION TRANSPORTATION PROBLEM}

In the production transportation problem, the suppliers are the producers of the commodity, and the model can be briefly characterized as follows [13]: $M$ producers of a certain homogeneous product, each of which has a production capacity of $A_{i}(i=1, \ldots, R)$ of units of goods supply its production to $N$ recipients. Each recipient reports the demand for $B_{j}$ units $(j=1, \ldots, N)$. The total production capacity of the plant is assumed to exceed the total demand. Additionally, the data are $c_{i j}$ - unit costs of transporting the goods from the $i$-th plant of the supplier to the $j$-th recipient, and $p_{i}$ - unit costs of production in the $i$-th plant. The goods have not yet been produced and it is necessary to decide where to produce them and how to send them to recipients so that the total costs of production and transport (and possibly storage of the surplus) are as low as possible.

This problem can be solved by linear optimization where [14]:

- $\quad$ set of decision variables for optimization tasks:

$x=\left\{x_{1}, \ldots, x_{1 n}\right\}^{T}$

- number of task variables:

$n=1, \ldots, N$

- objective function:

$F(x)$

- equality restrictions:

$h_{j}(x)=0$, dla $j=1, \ldots, n_{r}$

- inequality restrictions:

$g_{k}(x) \leq 0$, dla $k=1, \ldots, n_{n}$

The transport and production task can be easily simplified by:

a) the introduction of a fictitious customer $-\mathrm{O}_{\mathrm{N}+1}$, which will represent the unused production capacity of individual producers and whose demand is the difference between the sum of the producers 'production capacity and the sum of the customers' demand, i.e.

$B_{N+1}=\sum_{i=1}^{M} A_{i}-\sum_{j=1}^{N} B_{j}$

b) constructing a matrix of total transport and production costs $k_{i j}$ as follows:

$k_{i j}=p_{i}+c_{i j}($ dla $i=1, \ldots, M ; j=1, \ldots, N)$

$k_{i, N}+1=0$ (i.e.unused production capacity corresponds to costs equal to zero).

In the PTP task size $x_{i, N}+1$ is the unused production capacity of individual producers. 


\section{RESEARCH PROBLEM}

A certain group of companies producing alloying additions must plan their production and supply of raw materials for foundries in order to obtain the highest possible profit by minimizing delivery costs. The suppliers are companies producing alloy additions for the production of cast iron. Three companies $\left(M_{i}\right)$ supply four foundries $\left(N_{j}\right)$ with additions. Production companies capacities $\left(A_{i}\right)$, demand reported by foundries $\left(B_{j}\right)$, unit transport costs $\left(C_{i j}\right)$ from companies to the foundry, and unit costs of production of alloying additives in individual companies $\left(p_{i}\right)[\mathrm{PLN} / \mathrm{Mg}]$ are presented in Table 1. that factories will use their production capacity and store the surplus production for export. The unit storage costs in individual companies are: 5, 5, 6 PLN per Mg of alloying additions. An alternative optimization should also be made for the case where the production capacity of the companies is not fully utilized, and the companies will only produce as much alloying additions as the foundry needs.

Table 1 Production companies capacities $\left(A_{i}\right)$, demand reported by foundries $\left(B_{j}\right)$, unit transport costs $\left(c_{i j}\right)$ from companies to the foundry, and unit costs of production of alloying additives in individual companies $\left(p_{i}\right)$

\begin{tabular}{|c|c|c|c|c|c|c|}
\hline \multirow{2}{*}{$\begin{array}{l}\text { Suppliers } \\
\text { (Companies) }\end{array}$} & \multicolumn{4}{|c|}{ Recipients (Foundries) } & \multirow{2}{*}{$A_{i}[\mathrm{Mg}]$} & \multirow{2}{*}{$p_{i}[\mathrm{PLN} / \mathrm{Mg}]$} \\
\hline & $N_{1}$ & $\mathrm{~N}_{2}$ & $N_{3}$ & $\mathrm{~N}_{4}$ & & \\
\hline$M_{1}[\mathrm{PLN} / \mathrm{Mg}]$ & 50 & 40 & 50 & 20 & 100 & 1080 \\
\hline$M_{2}[\mathrm{PLN} / \mathrm{Mg}]$ & 40 & 80 & 70 & 30 & 50 & 1060 \\
\hline$M_{3}[\mathrm{PLN} / \mathrm{Mg}]$ & 60 & 60 & 70 & 80 & 80 & 1100 \\
\hline$B_{j}[\mathrm{Mg}]$ & 40 & 60 & 50 & 50 & $\begin{array}{l}\Sigma 230 \\
\Sigma 200\end{array}$ & \\
\hline
\end{tabular}

A production, transport and storage plan for alloying additions should be developed so that the total costs of production, transport and storage are as low as possible. This is an example of an open issue, because $\Sigma A_{i}=230>\Sigma B_{j}=200$. Decision variables $x_{i j}$ are the amount of alloying production of the $i$-th company $(I=1,2,3)$ delivered to the $j$-th foundry $(j=1, \ldots, 5)$, where $x_{i 5}$ being the number of castings that will remain in the warehouse of the $i$-th supplier. Before starting to build the model, you should determine the matrix of the total costs of production, transport and storage $-k_{i j}$. To the transport costs from the first company should be added the unit costs of alloying production in this company, i.e. $1080 \mathrm{PLN} / \mathrm{Mg}$, to the transport costs from the second company - 1060 PLN/Mg and from the third - 1100 PLN/Mg. The elements of the fifth column will be the sum of production and storage costs in individual factories producing alloying additions. This matrix has the form:

- $\quad$ for cases when companies will use their production capacity and store surplus production for export:

$k_{i j}=\left[\begin{array}{lllll}1130 & 1120 & 1130 & 1100 & 1085 \\ 1100 & 1140 & 1130 & 1090 & 1065 \\ 1160 & 1140 & 1170 & 1180 & 1106\end{array}\right]$

- $\quad$ or for a case in which the production capacity of the company is not fully utilized, and the company will only produce as much alloying additions as the foundry needs:

$k_{i j}=\left[\begin{array}{llll}1130 & 1120 & 1130 & 1100 \\ 1100 & 1140 & 1130 & 1090 \\ 1160 & 1140 & 1170 & 1180\end{array}\right]$

The total costs associated with the delivery are described as:

$F\left(x_{i j}\right)=\sum_{i=1}^{3} \sum_{j=1}^{5}\left(k_{i j} \cdot x_{i j}\right) \rightarrow \min$ 
This is an objective function, that should be minimized. The production capacity of the companies providing alloying additions, which are described by the following conditions for individual suppliers, should be taken into account here:

$\begin{aligned} & x_{11}+x_{12}+x_{13}+x_{14}+x_{15} \leq 100 \\ & x_{21}+x_{22}+x_{23}+x_{24}+x_{25} \leq 50 \\ & x_{31}+x_{32}+x_{33}+x_{34}+x_{35} \leq 80\end{aligned}$

and conditions for individual recipients (foundries):

$x_{11}+x_{21}+x_{31}=40$

$x_{12}+x_{22}+x_{32}=60$

$x_{13}+x_{23}+x_{33}=50$

$x_{14}+x_{24}+x_{34}=50$

$x_{15}+x_{25}+x_{35}=30$

In the latter condition, it was stated that $30 \mathrm{Mg}(230-200)$ of alloying additions should be stored in total in three companies supplying alloying additives.

The task defined in this way can be solved in the Octave environment [15]. This package is a computational environment that enables numerical and symbolic analysis. Thanks to the use of efficient numerical algorithms, it allows for quick and error-free solution of scientific and engineering problems. GNU octave is distributed under the terms of the GNU GPL. Octave is the free equivalent of the MATLAB environment, which is mostly compatible with it. The problem of choosing individual suppliers of alloying additions was solved using the glpk command. The GNU Linear Programming Kit (GLPK) is a software package intended for solving large-scale linear programming (LP), mixed integer programming (MIP), and other related problems [16]. GLPK uses the revised simplex method and the primal-dual interior point method for non-integer problems and the branchand-bound algorithm together with Gomory's mixed integer cuts for (mixed) integer problems [15].

\section{ANALYSIS OF THE RESULTS}

After calculations, optimal quantities of alloy additions for individual foundries were obtained. Figure 1 shows the assignment of suppliers and foundries, and the volume of delivery, assuming that factories producing alloying additions will use their production capacity and store excess production for export. The lowest costs of planned production and delivery will occur when the M1 company supplies raw materials for the N3 and N4 foundries, the M2 company for the N3 foundries, and the M3 company provides alloying additives for the N2 foundry. In addition, M2 and M3 companies should use N5 for export to utilize their production capacity. In turn, if the companies did not decide to produce their production surplus to the warehouse, then the optimal distribution of deliveries, assuming minimal production costs, is shown in Figure 2.



Figure 1 Optimal assignment of $\mathrm{M}$ suppliers to individual $\mathrm{N}$ foundries, in a situation when factories producing alloy additions will use their production capacity and store excess production 


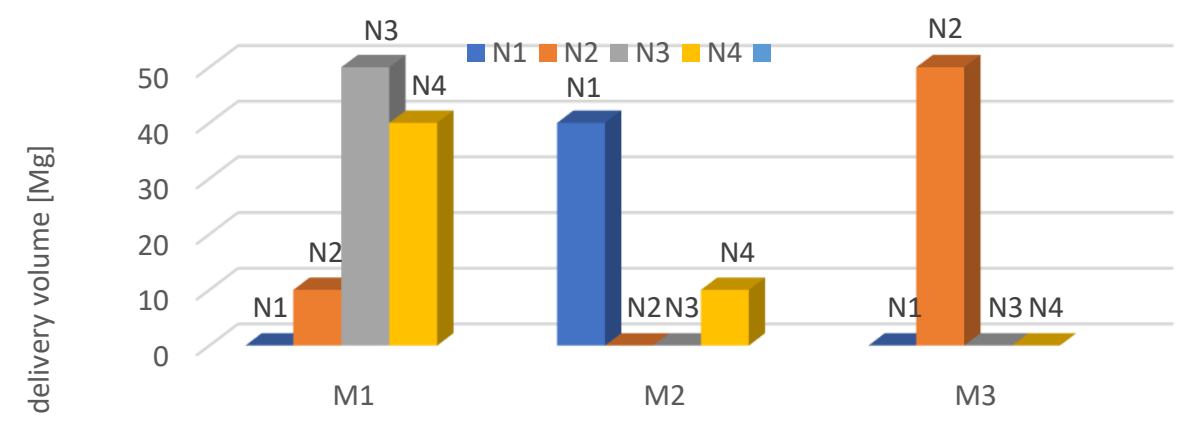

Figure 2 Optimal assignment of $\mathrm{M}$ suppliers to individual $\mathrm{N}$ foundries in a situation where the companies will not be fully used and will only produce as much alloying additions as the foundry needs

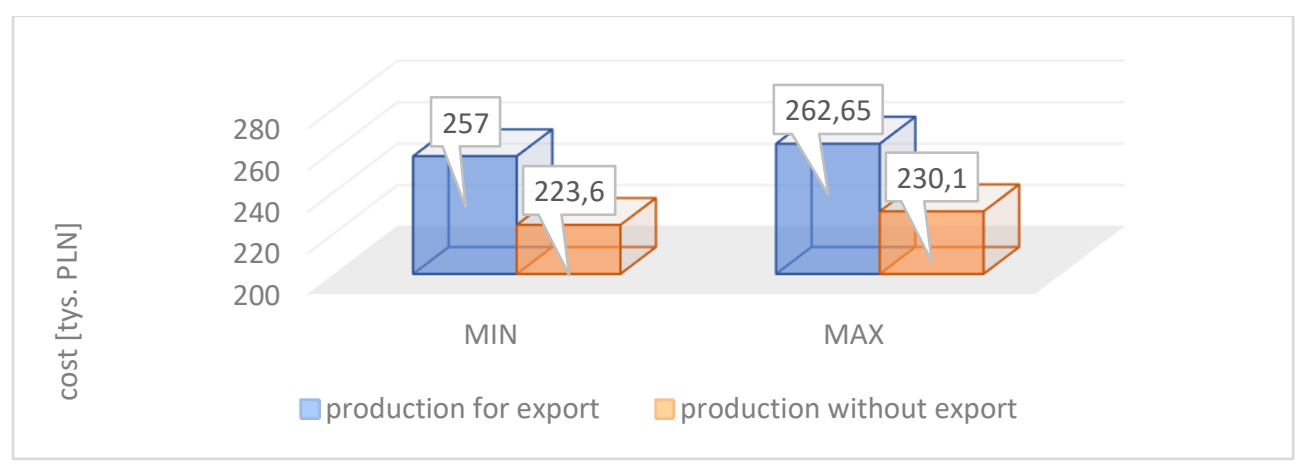

Figure 3 Total costs from the implementation of the order program for the criterion of minimizing and maximizing costs

Figure 3 presents a chart comparing the total cost of executing the order program for the two extreme cases. The first situation concerns the optimal solution when the costs are minimized. For comparison, the second shows the situation in which the costs were maximized.

The ranking shows that in the case of the most unfavorable selection of suppliers, in this situation, it will lead to an increase in costs by more than 5.5 thous. PLN for the case when the companies will use their production capacity and the excess production to be stored and by 6.5 thous. PLN, when the companies will not be fully used and will only produce as much alloying additions as the foundry needs.

\section{CONCLUSION}

The proposed analysis is the starting point for an efficient business planning process, where it is required to transform information from various areas (operations, sales, marketing and trading partners) into a common set of planning data and indicators.

At present, the approach towards matters of production process improvement must answer to contemporary developmental tendencies in a scope of company management in conditions of the market economy. Linear programming is one of the simplest ways to perform optimization. It helps solve some very complex optimization problems by making a few simplifying assumptions. It is possible to use the linear programming for the minimization of production costs as well as for the maximization of profits.

The presented example can, by analogy, be widened to a large number of suppliers and customers, as well as to months. This mathematical model find application in many engineering problems e.g. the problem of optimal using stores, realization the cheapest order, etc. It seems that the accumulated insights and results obtained may be useful in many areas of industry and research where exact planning and synchronization of 
processes are required e.g. assembly of electronic devices [17], biotechnology [18], surface layer treatment by nanopowders [19] and laser beam [20,21]. Some of ordering aspects probably should be considered in statistical model construction, because they may affect sampling schemes e.g. in ANOVA tests [22] or bootstrap resampling [23].

\section{REFERENCES}

[1] ZIMON, D. Ogólne wytyczne dotyczące zarządzania jakością i technologii w łańcuchu dostaw na przykład przemysłu metalurgicznego. Polish Journal of Management Studies. 2015, vol. 12, no. 2, pp. 212-219.

[2] NOWICKA-SKOWRON, M., ULEWICZ, R. Quality management in logistics processes in metal branch. In 24th International conference on metallurgy and materials, METAL 2015, pp. 1707-1712

[3] KOT, S., HAQUE, A.U., KOZLOVSKI, E. Strategic SCM's Mediating Effect on the Sustainable Operations: Multinational Perspective (2019) Organizacija, 52 (3), pp. 219-235.

[4] KLIMECKA-TATAR, D. Context of production engineering in management model of value stream flow according to manufacturing industry. Production Engineering Archives. 2018, vol. 21, pp.32-35.

[5] KRAMARZA, M., KRAMARZ, W. Transport issues in modelling of subcontracting in a production and logistics network. Procedia - Social and Behavioral Sciences. 2012, vol. 54, pp. 537-546.

[6] STEFKO, R., SLUSARCZYK, B., KOT, S., KOLMASIAK, C. Transformation on steel products distribution in Poland and Slovakia. Metalurgija. 2012, vol. 51 no. 1, pp. 133-136.

[7] BARD, J.F., NANANUKUL, N. A branch-and-price algorithm for an integrated production and inventory routing problem, Computers \& Operations Research. 2010, vol. 37, no. 12, pp. 2202-2217.

[8] DRLJAČA, M. Reversible supply chain in function of competitiveness. Production Engineering Archives. 2019, vol. 22, pp.30-35.

[9] ULEWICZ, R., SELEJDAK, J., BORKOWSKI, S., JAGUSIAK-KOCIK, M. Process management in the cast iron foundry. In 22nd International conference on metallurgy and materials, METAL 2013, pp. 1926-1931.

[10] LUKAČ, Z., HUNJET, D., NERALIĆ, L. Solving the production-transportation problem in the petroleum industry. Revista Investigación Operacional. 2008, vol. , 29 no 1, pp. 63-70.

[11] KRYNKE, M., MIELCZAREK, K. Applications of linear programming to optimize the cost-benefit criterion in production processes. MATEC Web of Conferences. 2018, vol.183, pp. 1-6.

[12] DEHGHANBAGHI, N, SAJADIEH, M.S. Joint optimization of production, transportation and pricing policies of complementary products in a supply chain. Computers \& Industrial Engineering, 2017, vol. 107, pp. 150-157.

[13] MICHLOWICZ, E, SMOLIŃSKA, K, ZWOLIŃSKA, B. Optymalizacja dystrybucji w zadaniach transportowoprodukcyjnych. Logistyka. 2015, vol 4. pp. 4898-4905.

[14] KRYNKE, M., MIELCZAREK, K., VAŠKO, A. Analysis of the problem of staff allocation to work stations, Quality Production Improvement. De Gruyter Poland, 2019, vol. 1, no. 1, pp. 545-550.

[15] NAGAR, S. Introduction to Octave: For Engineers and Scientists. Apress, NewYork, 2018.

[16] PIECHNA, A. Zadanie programowania liniowego w środowisku GNU Octave. Projektowanie i konstrukcje inżynierskie. 2012, vol. 55, pp. 58-62.

[17] PIETRASZEK, J., GADEK-MOSZCZAK, A.,TORUNSKI, T. Modeling of Errors Counting System for PCB Soldered in the Wave Soldering Technology. Advanced Materials Research. 2014, vol. 874, pp. 139-143.

[18] SKRZYPCZAK-PIETRASZEK, E., KWIECIEN, I., GOLDYN, A., PIETRASZEK, J. HPLC-DAD analysis of arbutin produced from hydroquinone in a biotransformation process in Origanum majorana L. shoot culture. Phytochemistry Letters. 2017, vol. 20, pp. 443-448.

[19] KORZEKWA, J., BARA M., PIETRASZEK, J., PAWLUS, P. Tribological behaviour of $\mathrm{Al}_{2} \mathrm{O}_{3} /$ inorganic fullerene-like $\mathrm{WS}_{2}$ composite layer sliding against plastic. International Journal of Surface Science and Engineering. 2016, vol. 10, pp. 570-584.

[20] RADEK, N., BARTKOWIAK, K. Laser treatment of electro-spark coatings deposited in the carbon steel substrate with using nanostructured WC-Cu electrodes. Physics Procedia. 2012, vol. 39, pp. 295-301. 
[21] GADEK-MOSZCZAK, A., RADEK, N., WRONSKI, S., TARASIUK, J. Application the 3D Image Analysis Techniques for Assessment the Quality of Material Surface Layer Before and After Laser Treatment. Advanced Materials Research. 2014, vol. 874, pp. 133-138.

[22] PIETRASZEK, J., KOLOMYCKI, M., SZCZOTOK, A., DWORNICKA, R. The Fuzzy Approach to Assessment of ANOVA Results. Lecture Notes in Artificial Intelligence. 2016, vol. 9875, pp. 260-268.

[23] PIETRASZEK, J., GADEK-MOSZCZAK, A. The Smooth Bootstrap Approach to the Distribution of a Shape in the Ferritic Stainless Steel AISI 434L Powders. Solid State Phenomena. 2012, vol. 197, pp. 162-167. 